The FASEB Journal express article10.1096/fj.04-2882fje. Published online February 16, 2005.

\title{
Hydrogen peroxide is a diffusible paracrine signal for the induction of epithelial cell death by activated myofibroblasts
}

\author{
Meghna Waghray, Zongbin Cui, Jeffrey C. Horowitz, Indhu M. Subramanian, \\ Fernando J. Martinez, Galen B. Toews, and Victor J. Thannickal \\ Division of Pulmonary and Critical Care Medicine, Department of Medicine, University of \\ Michigan Medical Center, 1150 W. Medical Center Dr., Ann Arbor MI 48109 \\ Corresponding author: Victor J. Thannickal, Division of Pulmonary and Critical Care Medicine, \\ University of Michigan Medical Center, 6301 MSRB III, 1150 W. Medical Center Dr., Ann \\ Arbor, MI 48109 USA. E-mail: vjt@umich.edu
}

\section{ABSTRACT}

Cell-cell signaling roles for reactive oxygen species (ROS) generated in response to growth factors/cytokines in nonphagocytic cells are not well defined. In this study, we show that fibroblasts isolated from lungs of patients with idiopathic pulmonary fibrosis (IPF) generate extracellular hydrogen peroxide $\left(\mathrm{H}_{2} \mathrm{O}_{2}\right)$ in response to the multifunctional cytokine, transforming growth factor- $\beta 1$ (TGF- $\beta 1$ ). In contrast, TGF- $\beta 1$ stimulation of small airway epithelial cells (SAECs) does not result in detectable levels of extracellular $\mathrm{H}_{2} \mathrm{O}_{2}$. IPF fibroblasts independently stimulated with TGF- $\beta 1$ induce loss of viability and death of overlying SAECs when cocultured in a compartmentalized Transwell system. These effects on SAECs are inhibited by the addition of catalase to the coculture system or by the selective enzymatic blockade of $\mathrm{H}_{2} \mathrm{O}_{2}$ production by IPF fibroblasts. IPF fibroblasts heterogeneously express $\alpha$-smooth muscle actin stress fibers, a marker of myofibroblast differentiation. Cellular localization of $\mathrm{H}_{2} \mathrm{O}_{2}$ by a fluorescent-labeling strategy demonstrated that extracellular secretion of $\mathrm{H}_{2} \mathrm{O}_{2}$ is specific to the myofibroblast phenotype. Thus, myofibroblast secretion of $\mathrm{H}_{2} \mathrm{O}_{2}$ functions as a diffusible death signal for lung epithelial cells. This novel mechanism for intercellular ROS signaling may be important in physiological/pathophysiological processes characterized by regenerating epithelial cells and activated myofibroblasts.

Key words: TGF- $\beta 1 \bullet$ fibrosis $\bullet$ oxidative stress $\bullet$ tissue repair $\bullet$ apoptosis

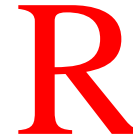
eactive oxygen species (ROS), such as superoxide anion $\left(\mathrm{O}_{2}{ }^{-}\right)$, hydrogen peroxide $\left(\mathrm{H}_{2} \mathrm{O}_{2}\right)$, and hydroxyl radical $(\mathrm{OH} \cdot)$, participate in cell signaling and/or injury $(1,2)$. ROS vary in their inherent reactivities, stability, chemistry, and diffusibility. $\mathrm{H}_{2} \mathrm{O}_{2}$, in most biological contexts, is generally less reactive and more long-lived than either $\mathrm{O}_{2}{ }^{-{ }^{-}}$or $\mathrm{OH} \cdot$; moreover, $\mathrm{H}_{2} \mathrm{O}_{2}$ is lipid-soluble and can diffuse across biological membranes. Most studies of $\mathrm{H}_{2} \mathrm{O}_{2}$ have focused on its role in mediating intracellular signal transduction by its ability to oxidize cysteine residues in the catalytic domains of protein tyrosine phosphatases $(3,4)$. Extracellular effects have been demonstrated by exogenous addition of $\mathrm{H}_{2} \mathrm{O}_{2}$ directly to target 
cells (5, 6). Specific role(s) for cell-derived $\mathrm{H}_{2} \mathrm{O}_{2}$ as an extracellular/paracrine signaling molecule in cell-cell communication has not been well defined.

Nonphagocytic cells are known to generate both intracellular and extracellular oxidants in response to physiological ligands $(1,2)$. In most cases, the enzymatic sources of ligandstimulated ROS generation in such cells belong to the family of plasma membrane-associated NAD(P)H oxidases (Nox enzymes). Previous studies from our laboratory demonstrated that, while mitogenic growth factors stimulate intracellular oxidants required for proliferative cellular responses, TGF- $\beta 1$ primarily induces extracellular $\mathrm{H}_{2} \mathrm{O}_{2}$ secretion in human lung fibroblasts (1). Ohba et al. (7) showed that $\mathrm{H}_{2} \mathrm{O}_{2}$ may function in an autocrine manner to up-regulate early growth response-1 (egr-1) gene in mouse osteoblastic cells. Other redox-dependent effects of TGF- $\beta 1$-induced ROS production include the induction of plasminogen activator-1 (8), extracellular matrix proteins $(9,10)$, and tissue inhibitors of matrix metalloproteinases $(11)$. Thus, although a number of autocrine and/or intracellular effects of ROS have been reported, paracrine and/or intercellular signaling role(s) have not, to our knowledge, been described previously.

Fibroblasts/mesenchymal cells are active participants in injury and repair processes, and appear to survive, and even thrive, under such conditions. Cultured fibroblasts that actively generate ROS do not, in general, appear to be under increased "stress," and in fact, are resistant to serum deprivation-induced apoptosis $(12,13)$. Moreover, TGF- $\beta 1$-induced $\mathrm{H}_{2} \mathrm{O}_{2}$ production in cultured human lung fibroblasts is associated with protein tyrosine phosphorylation (14), myofibroblast differentiation (15), and enhanced mitogenic responses to fibroblast growth factors (16). This supports the general concept that fibroblasts may be resistant to the potential injurious effects of ROS when produced at low steady-state levels in a regulated manner. In contrast, epithelial cells may be relatively more sensitive to oxidative stress stimuli such as hyperoxia or exogenous $\mathrm{H}_{2} \mathrm{O}_{2}$ $(5,17,18)$.

Dysregulated repair of adult epithelium-lined tissues may be associated with an exuberant fibrotic response with activation of mesenchymal cells and an inability to regenerate/reconstitute injured epithelium. Human fibrotic diseases in several organ systems involve the persistent activation of myofibroblasts in injured tissues. The expression and activation of TGF- $\beta 1$ is critical for the emergence, activation and persistence of myofibroblastic cells. Activated myofibroblastic foci in areas of tissue injury and fibrosis are in close proximity to damaged epithelium. Studies in idiopathic pulmonary fibrosis (IPF), a chronic fibrosing disease of the lung, suggest that alveolar epithelial cells overlying fibroblastic foci undergo increased rates of cell death (19-21).

In this study, we first confirmed the $\mathrm{H}_{2} \mathrm{O}_{2}$-generating capacity of fibroblasts isolated from adult patients with IPF. The potential that $\mathrm{H}_{2} \mathrm{O}_{2}$ secreted by IPF fibroblasts might induce death of small airway epithelial cells (SAECs) was examined in a compartmentalized coculture system. We also tested the hypothesis that the $\mathrm{H}_{2} \mathrm{O}_{2}$-generating capacity of heterogeneous IPF fibroblasts may be specific to the myofibroblast phenotype. 


\section{MATERIALS AND METHODS}

\section{Cells and culture systems}

\section{Fibroblasts/mesenchymal cells from IPF patients}

Adherent fibroblasts/mesenchymnal cells were isolated from patients with established diagnoses of IPF according to ATS/ERS criteria (22). Research protocols involving human samples/subjects received prior approval by the Institutional Review Board at the University of Michigan. Briefly, tissue explants were made adherent on tissue culture plastic and selectively grown in medium consisting of Dulbecco's modified Eagle’s medium (DMEM; GIBCO, Grand Island, NY) supplemented with 10\% fetal bovine serum (FBS; Sigma, St. Louis, MO), 100 U/ml penicillin/streptomycin (Sigma), and fungizone (GIBCO); medium was changed every 2 days. Studies were performed on passage 3-6 of spindle-shaped cells that uniformly stained positive for prolyl-4-hydroxylase, an enzyme that posttranslationally modifies collagen. Cells were plated on $35 \mathrm{~mm}$ cell culture dishes (for $\mathrm{H}_{2} \mathrm{O}_{2}$ assays) at a density of $5 \times 10^{5}$ cells/dish or on the lower wells of six-well Transwell coculture system (BD Biosciences, Bedford, MA). At 80-90\% confluence, cells were growth-arrested for $48 \mathrm{~h}$ in DMEM with 0.01\% FBS before treatment with/without TGF- $\beta 1$. Following $16 \mathrm{~h}$, cells were washed twice with HBSS before $\mathrm{H}_{2} \mathrm{O}_{2}$ measurements or insertion of the upper chambers (containing SAECs) in the Transwell coculture system.

\section{Small airway epithelial cells}

Small airway epithelial cells (SAECs) were obtained from Clonetics (Cambrex Biosciences, Walkersville, MD), and cells were grown in small airway basal medium (SABM) supplemented with growth factors (Clonetics). Medium was changed every 2 days. Studies were performed on passage 2 cells. Cells were seeded on porous polyethylene-terephthalate (PET) membranes $(0.4$ $\mu \mathrm{m}$ pore size) of the upper chambers of the Transwell coculture system. These upper chambers were removed from the coculture system and placed in sterile $100 \mathrm{~mm}$ cell culture dishes and SAECs cultured separately until near confluence. IPF fibroblasts were initially grown in the lower wells of the Transwell system (without upper chambers, as described above); at initiation of coculture, SAECs were introduced by replacing the upper chambers back in the Transwell system. SAECs were analyzed for cell counts, proliferation, and apoptosis/necrosis at $48 \mathrm{~h}$ following coculture.

\section{Reagents}

Porcine platelet-derived TGF- $\beta 1$ was obtained from R\&D Systems (Minneapolis, MN). Catalase derived from bovine erythrocytes was purchased from Sigma. Diphenyliodonium (DPI) was from ICN Biochemicals (Costa Mesa, CA). All other reagents were obtained from Sigma, unless otherwise stated.

\section{Measurement of cellular $\mathrm{H}_{2} \mathrm{O}_{2}$ release}

$\mathrm{H}_{2} \mathrm{O}_{2}$ release from cultured fibroblasts into the overlying medium was assayed using a fluorimetric method, as described previously (12). This fluorimetric assay is based on the 
conversion of homovanillic acid, a substituted phenol, to its fluorescent dimer in the presence of $\mathrm{H}_{2} \mathrm{O}_{2}$ and horseradish peroxidase (HRP). At $16 \mathrm{~h}$ of exposure to TGF- $\beta 1$, all cells were washed with Hank's balanced salt solution (HBSS), $\mathrm{pH}$ 7.4, and then incubated with the reaction mixture containing $100 \mu \mathrm{M}$ homovanillic acid, $5 \mathrm{U} / \mathrm{ml}$ HRP, type VI, and $1 \mathrm{mM}$ HEPES in HBSS without phenol red, $\mathrm{pH}$ 7.4. This solution was collected following 90-min incubation, the $\mathrm{pH}$ was adjusted to 10.0 with $0.1 \mathrm{M}$ glycine- $\mathrm{NaOH}$ buffer, and fluorescence was measured at excitation and emission wavelengths of 321 and 421, respectively. Control reaction buffer without cells was incubated to correct for any spontaneous dimerization of homovanillic acid. The exact $\mathrm{H}_{2} \mathrm{O}_{2}$ concentrations of solutions used to plot standard curves was determined spectrophotometrically at $240 \mathrm{~nm}$ using an extinction coefficient of $43.6 \mathrm{M}^{-1 . \mathrm{cm} 1}$.

\section{Measurements for cell viability, apoptosis/necrosis, and proliferation}

\section{Cell counts by Coulter counter}

Cell viability was assessed by direct counting of cells using a model ZM Coulter counter (Coulter Electronics, Hialeah, FL). Briefly, after removal of medium, culture dishes were washed with HBSS, incubated with $1.0 \mathrm{ml}$ of trypsin-EDTA for 2-3 min, and rapidly suspended in solution by pipetting. A $0.2 \mathrm{ml}$ aliquot of cell suspension was then diluted for counting in the coulter counter.

\section{Apoptosis/necrosis assay}

Apoptosis is characterized by the early exposure of phosphatidylserine (PS) at the outer surface of the plasma membrane; early necrosis (oncosis) has also recently been described to expose PS moieties on the outer plasma membrane (23). Assays for apoptosis/oncosis were performed by detection of PS by immunofluorescence staining. Briefly, cells were fixed with $4 \%$ formaldehyde and washed three times with cold phosphate-buffered saline before blocking with $1 \%$ bovine serum albumin for $15 \mathrm{~min}$. Monoclonal antibody to PS (cell signaling solutions, Upstate, Waltham, MA) was added at a dilution of 1:25 for $1 \mathrm{~h}$ followed by FITC-labeled secondary antibody for $1 \mathrm{~h}$. Counterstaining was with DAPI for nuclear staining. Cells were visualized and photographed using a Zeiss fluorescence microscope (Zeiss IM 35 inverted microscope, Oberkochen, Germany). The percent cell death under each condition were quantitated by dividing PS $(+)$ cells by total number of cells and taking the average of three separate/random fields of at least 100 cells per field.

\section{Proliferation assay}

Cell proliferation was measured with a nonisotopic enzyme immunoassay for BrdU incorporation (BrdU cell proliferation assay kit, Oncogene Research Products, Nottingham, UK), according to the manufacturer's instructions. Cells were labeled with BrdU for $24 \mathrm{~h}$. The medium was removed, and cells were fixed with fixative/denaturing solution for $30 \mathrm{~min}$. The fixative was then removed, and $100 \mu \mathrm{l}$ of anti-BrdU antibody added for $1 \mathrm{~h}$. After washing, 100 $\mu \mathrm{l}$ of HRP-conjugated goat-anti-mouse secondary antibody was added for $15 \mathrm{~min}$. After repeat washing, $100 \mu \mathrm{l}$ of substrate was added and the plate incubated in the dark for 15 min followed by $100 \mu \mathrm{l}$ of "stop solution" supplied by the manufacturer. Absorbance was read on an ELISA plate reader at dual wavelengths of $450-540 \mathrm{~nm}$. "Background" absorbance of cells receiving no 
primary antibody was subtracted, and a relative proliferation index was calculated by dividing the corrected absorbance by cell counts (measured by Coulter counter, described above).

\section{Identification of $\mathrm{H}_{2} \mathrm{O}_{2}$-producing cells and immunofluorescence detection}

$\mathrm{H}_{2} \mathrm{O}_{2}$, in the presence of HRP, catalyzes the crosslinking of a phenolic compound, tyramide conjugated to FITC, with tyrosine residues of matrix proteins in close proximity to the site of cellular $\mathrm{H}_{2} \mathrm{O}_{2}$ generation (24). We used this fluorophore-labeling technique to identify cells that are actively secreting $\mathrm{H}_{2} \mathrm{O}_{2}$. Cultured IPF fibroblasts simulated with/without TGF- $\beta 1$ were first washed with HBSS and incubated with $1 \mathrm{ml}$ of HBSS containing $1 \mathrm{mM}$ HEPES buffer (pH 7.4), $5 \mathrm{U} / \mathrm{ml} \mathrm{HRP}$, and 1:1000 dilution of freshly reconstituted tyramide-FITC (PerkinElmer Life Sciences, Boston, MA). Tyramide-FITC was supplied by the manufacturer as lyophilized powder (weight not indicated). Initial reconstitution was with $\mathrm{Me}_{2} \mathrm{SO}$ using the 1:10 volume recommended by the manufacturer. The final concentration of tyramide-FITC used in our assays amounted to one-half that recommended for use in signal amplification protocols (kit insert, PerkinElmer Life Sciences). Cells were allowed to incubate for $1 \mathrm{~h}$ at $37^{\circ} \mathrm{C}$ in the buffer solution containing tyramide-FITC and HRP. Cells were then washed two times with HBSS and fixed in $4 \%$ formaldehyde for immunofluorescence staining with a monoclonal antibody to $\alpha$-SMA (Dako, Carpenteria, CA; 1:25 diluton) followed by TRITC-conjugated secondary antibody (1:40 dilution). Cells were visualized and photographed using a Zeiss fluorescence microscope (Zeiss IM 35 inverted microscope).

\section{Statistical analysis}

Statistical analysis was performed using Student's $t$ test and one-way ANOVA with Bonferonni post test using GraphPad Prism version 3.0 for Windows, GraphPad Software (San Diego, CA, www.graphpad.com). Statistical significance in all cases were defined at $P<0.05$.

\section{RESULTS}

\section{IPF fibroblasts, but not SAECs, secrete $\mathrm{H}_{2} \mathrm{O}_{2}$ into the extracellular space in response to TGF- $\beta 1$}

Certain nonphagocytic cells generate ROS in specific cellular compartments in response to a variety of growth factor ligands (2). Our previous studies demonstrated that TGF- $\beta 1$ stimulates extracellular $\mathrm{H}_{2} \mathrm{O}_{2}$ generation in normal human fetal lung fibroblasts (IMR-90), an effect that is maximal after $16 \mathrm{~h}$ and is sustained for up to $48 \mathrm{~h}$ after initial stimulation $(1,12)$. Whether similar responses occur in adult human lung fibroblasts, particularly those derived from injured/fibrotic tissues, is not known. We isolated fibroblasts from explant cultures of lung tissue from patients with IPF. IPF fibroblasts at passage 3-5 were stimulated with/without TGF- $\beta 1$ (2 $\mathrm{ng} / \mathrm{ml}$ ) in the absence of serum for $16 \mathrm{~h}$, and extracellular $\mathrm{H}_{2} \mathrm{O}_{2}$ production was measured. IPF fibroblasts generated low constitutive levels of extracellular $\mathrm{H}_{2} \mathrm{O}_{2}$ that was markedly enhanced

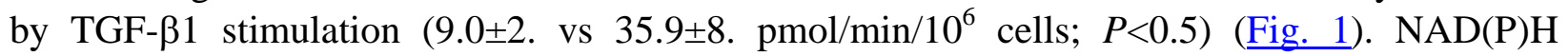
oxidases (Nox) are flavoenzymes that have recently been shown to be expressed in nonphagocytic cells. Diphenyliodonium (DPI) is an inhibitor of flavoenzymes (25). Pretreatment with DPI (10 $\mu \mathrm{M}$ for $30 \mathrm{~min})$ completely abolished both constitutive and TGF- $\beta 1$-induced $\mathrm{H}_{2} \mathrm{O}_{2}$ 
secretion by IPF fibroblasts, suggesting that a Nox-like enzyme activity is responsible for the extracellular $\mathrm{H}_{2} \mathrm{O}_{2}$ production in these cells.

SAECs in monolayer culture were similarly assayed for extracellular $\mathrm{H}_{2} \mathrm{O}_{2}$ release in the absence/presence of TGF- $\beta 1$. These cells did not release detectable amounts of $\mathrm{H}_{2} \mathrm{O}_{2}$ into the extracellular space (Fig. 1). These results suggest that IPF fibroblasts, but not SAECs, generate markedly increased amounts of extracellular $\mathrm{H}_{2} \mathrm{O}_{2}$ in response to TGF- $\beta 1$.

\section{TGF- $\beta 1$-stimulated IPF fibroblasts induce loss of viability of SAECs by an $\mathrm{H}_{2} \mathrm{O}_{2}$-dependent mechanism}

Exogenous $\mathrm{H}_{2} \mathrm{O}_{2}$ has been previously shown to regulate diverse cellular responses, including proliferation and apoptosis $(2,5,18)$. To determine if endogenous generation of $\mathrm{H}_{2} \mathrm{O}_{2}$ by TGF$\beta 1$-stimulated IPF fibroblasts may influence the viability of SAECs in a paracrine manner, we designed a coculture system in which these cell types were allowed to communicate via a $0.4 \mu \mathrm{m}$ permeable membrane that does not allow for direct cell-cell contact. IPF fibroblasts were grown in the lower wells of the Transwell coculture system and SAECs on permeable membranes in upper chambers with removable inserts (Fig. 2A). Both cell types were seeded and cultured independently before coculture; IPF fibroblasts were stimulated with/without TGF- $\beta 1$ ( 2 ng/ml) for $16 \mathrm{~h}$ and washed thoroughly to remove any preformed soluble factor(s) before introduction of inserts (upper chambers) containing SAECs; IPF fibroblasts continue to actively secrete $\mathrm{H}_{2} \mathrm{O}_{2}$ extracellularly even after this washing step (Fig. 1). Cells were cocultured for $48 \mathrm{~h}$, and SAEC counts were assayed by Coulter counting. TGF- $\beta 1$-stimulated IPF fibroblasts induced loss of viability of SAECs with reduction in cell numbers, an effect that was reversed by addition of catalase to the coculture system or by pretreatment of IPF fibroblasts by DPI (Fig. $2 B$ ). This suggests that $\mathrm{H}_{2} \mathrm{O}_{2}$ secreted by IPF cells in response to TGF- $\beta 1$ stimulation functions as a diffusible paracrine signal for loss of SAEC viability.

\section{$\mathrm{H}_{2} \mathrm{O}_{2}$-mediated loss of SAEC viability is mediated by induction of apoptosis/necrosis}

Reduction in cell numbers of SAECs in coculture with TGF- $\beta 1$-treated IPF fibroblasts may be related to decreased proliferation (although cells are quiescent in serum-free medium during coculture) or increased cell death by apoptotic/necrotic mechanisms. Incorporation of BrdU, as a measure of cell proliferation, of SAECs did not show significant differences between these groups (data not shown). PS is a lipid moiety of the plasma membrane that is externalized during apoptosis, and possibly early necrosis (23). To determine if induction of epithelial cell death may account for the loss of SAEC viability, SAECs in coculture with IPF fibroblasts were assayed for cell death by PS staining. Immunofluorescent staining for PS was highest in SAECs cocultured with TGF- $\beta 1$-treated IPF fibroblasts (ig. $3 A$ ); this was quantitated by assessment of percent PSpositive cells (Fig. 3B), as described in Materials and Methods. Similar to results of SAEC viability studies, addition of catalase or pretreatment of IPF fibroblasts with DPI resulted in an inhibition of the death-inducing effects of TGF- $\beta 1$-treated IPF fibroblasts on SAECs. These results, together with the observations on SAEC viability, suggest that the augmented secretion of $\mathrm{H}_{2} \mathrm{O}_{2}$ by IPF fibroblasts induces apoptotic/necrotic death of adjacent epithelial cells. 


\section{Extracellular $\mathrm{H}_{2} \mathrm{O}_{2}$ secretion by IPF fibroblasts is specific to myofibroblasts}

IPF tissue-derived fibroblasts represent a heterogeneous population of cells, including myofibroblasts. To determine if the capacity for $\mathrm{H}_{2} \mathrm{O}_{2}$ secretion was specific to this cell population, we used a peroxidase-dependent tyrosine labeling technique developed in our laboratory (24). This tyramide-FITC assay system identifies crosslinked ECM proteins directly overlying cells that actively secrete $\mathrm{H}_{2} \mathrm{O}_{2}$; the presence of HRP in this system allows for the rapid reaction of $\mathrm{H}_{2} \mathrm{O}_{2}$ with $\mathrm{HRP}$ to form a highly reactive intermediate radical that reacts with tyrosine residues on ECM proteins in close proximity to the site of $\mathrm{H}_{2} \mathrm{O}_{2}$ generation. TyramideFITC labeling for $\mathrm{H}_{2} \mathrm{O}_{2}$ showed a heterogeneous pattern that is closely associated with $\alpha$-SMApositive myofibroblasts (Fig. 4). Catalase and DPI blocks the tyramide-FITC reaction (Fig. 4), suggesting specificity of this labeling reaction for $\mathrm{H}_{2} \mathrm{O}_{2}$ production. These findings indicate that myofibroblasts are the principal cells responsible for extracellular $\mathrm{H}_{2} \mathrm{O}_{2}$ production by these heterogeneous populations of IPF fibroblasts.

\section{DISCUSSION}

Complex tissue remodeling processes such as in normal development, carcinogenesis, and injury/repair are characterized by intimate crosstalk between mesenchymal cells and epithelial cells. Epithelial-mesenchymal interactions are typically mediated by soluble factors, cell-cell adhesion complexes, and, indirectly, by the surrounding ECM. Soluble factors classically involve growth factors/cytokines, lipid mediators, and reactive gaseous molecules such as NO and CO. ROS are reduced metabolic derivatives of $\mathrm{O}_{2}$ with the capacity to function as intracellular signaling molecules. Biological effects of extracellular $\mathrm{H}_{2} \mathrm{O}_{2}$ have been primarily studied by adding exogenous $\mathrm{H}_{2} \mathrm{O}_{2}$ to target cells (6) or by examining autocrine effects on the $\mathrm{H}_{2} \mathrm{O}_{2}$-producing cells themselves (2). No studies, to our knowledge, have demonstrated a paracrine cell-cell signaling role for endogenously generated $\mathrm{H}_{2} \mathrm{O}_{2}$ in a physiologically relevant context. In this study, we provide strong evidence for a paracrine signaling role for $\mathrm{H}_{2} \mathrm{O}_{2}$, secreted by a distinct population of mesenchymal cells, which induces death of adjacent epithelial cells (Fig. 5).

Our findings that TGF- $\beta 1$ induces extracellular $\mathrm{H}_{2} \mathrm{O}_{2}$ production in adult fibrotic-lung fibroblasts extend our previous observations of similar effects in human fetal lung fibroblasts (IMR-90), although the rates of extracellular $\mathrm{H}_{2} \mathrm{O}_{2}$ produced are significantly lower in IMR-90 cells (12). Moreover, given the inherent heterogeneity of IPF fibroblasts and relative lack of $\mathrm{H}_{2} \mathrm{O}_{2}$ production by nonmyofibroblastic cells in this population, the amount of $\mathrm{H}_{2} \mathrm{O}_{2}$ secreted by myofibroblasts is likely to be even higher on a per cell basis. Lowering of the steady-state levels of $\mathrm{H}_{2} \mathrm{O}_{2}$ at the interface of activated IPF myofibroblasts (by catalase or enzymatic inhibition) inhibits the induction of epithelial cell death by TGF- $\beta 1$ signaling of mesenchymal cells, supporting a role for $\mathrm{H}_{2} \mathrm{O}_{2}$ in paracrine signaling. These effects were observed in a coculture system of epithelial-mesenchymal cells that were separated by a porous membrane, indicating that $\mathrm{H}_{2} \mathrm{O}_{2}$ signaling in this context is mediated by a mechanism that involves diffusion of $\mathrm{H}_{2} \mathrm{O}_{2}$ over short distances $(<1 \mathrm{~mm})$ and does not require direct cell-cell contact.

There is significant evidence supporting direct and indirect role(s) for exogenous $\mathrm{H}_{2} \mathrm{O}_{2}$ or other forms of oxidative stress (such as hyperoxia) on the induction of epithelial cell apoptosis/necrosis (5, 17, 18, 26). Mechanisms for this effect may involve induction of Fas 
ligand (26) and/or p53-induced cell death (26-28). Moreover, TGF- $\beta 1$ itself has been shown to induce Fas-mediated apoptosis of epithelial cells (29). It is unlikely that direct signaling of epithelial cells by TGF- $\beta 1$ accounts for the findings in our study since fibroblasts and epithelial cells were grown separately and washed thoroughly before coculture. Induction by fibroblasts of TGF- $\beta 1$ that then acts as a paracrine mediator on epithelial cells is possible, but TGF- $\beta 1$ is usually secreted by cells in an inactive, latent form. Fas, p53, and mitochondrial pathways have shown to be activated in alveolar epithelial cells of patients with IPF $(20,30,31)$. It is conceivable that, given the findings in this report, activation of these pathways in alveolar epithelial cell death may be mediated by $\mathrm{H}_{2} \mathrm{O}_{2}$ secreted by myofibroblasts in close proximity to injured/dying epithelial cells in IPF. Uhal and coworkers have described the secretion of angiotensin peptides as a mechanism for alveolar epithelial cell death adjacent to underlying myofibroblasts in advanced fibrotic human lung $(19,32,33)$. Further studies are required to determine if there is crosstalk between angiotensin metabolism and oxidative stress.

Our studies provide strong support for the concept that $\mathrm{H}_{2} \mathrm{O}_{2}$ secretion is induced selectively in myofibroblast-differentiated cells. These cells represent a highly activated, secretory, and contractile cell phenotype that plays central roles in tissue remodeling and fibrosis (34). Myofibroblast-epithelial cell interactions in such conditions likely represent a dysregulated tissue repair process. The results of the current study indicate myofibroblast-induced epithelial cell death through oxidant-mediated mechanism(s) that may, in vivo, promote repetitive cycles of epithelial injury, aberrant repair responses, and progressive organ fibrosis. Moreover, this study supports a paracrine signaling role for $\mathrm{H}_{2} \mathrm{O}_{2}$ by a specific cellular source that may have broader implications in other physiological/pathophysiological processes characterized by myofibroblast activation.

\section{ACKNOWLEDGMENTS}

This work was supported by National Institutes of Health grants R01 HL67967 and P50 HL74024.

\section{REFERENCES}

1. Thannickal, V. J., Day, R. M., Klinz, S. G., Bastien, M. C., Larios, J. M., and Fanburg, B. L. (2000) Ras-dependent and -independent regulation of reactive oxygen species by mitogenic growth factors and TGF-beta1. FASEB J. 14, 1741-1748

2. Thannickal, V. J., and Fanburg, B. L. (2000) Reactive oxygen species in cell signaling. Am. J. Physiol. Lung Cell. Mol. Physiol. 279, L1005-L1028

3. Lee, S. R., Kwon, K. S., Kim, S. R., and Rhee, S. G. (1998) Reversible inactivation of protein-tyrosine phosphatase 1B in A431 cells stimulated with epidermal growth factor. $J$. Biol. Chem. 273, 15366-15372

4. Jones, D. P., Go, Y. M., Anderson, C. L., Ziegler, T. R., Kinkade, J. M., Jr., and Kirlin, W. G. (2004) Cysteine/cystine couple is a newly recognized node in the circuitry for biologic redox signaling and control. FASEB J. 18, 1246-1248 
5. Goldkorn, T., Balaban, N., Shannon, M., Chea, V., Matsukuma, K., Gilchrist, D., Wang, H., and Chan, C. (1998) H2O2 acts on cellular membranes to generate ceramide signaling and initiate apoptosis in tracheobronchial epithelial cells. J. Cell Sci. 111, 3209-3220

6. Kamsler, A., and Segal, M. (2004) Hydrogen peroxide as a diffusible signal molecule in synaptic plasticity. Mol. Neurobiol. 29, 167-178

7. Ohba, M., Shibanuma, M., Kuroki, T., and Nose, K. (1994) Production of hydrogen peroxide by transforming growth factor-beta 1 and its involvement in induction of egr-1 in mouse osteoblastic cells. J. Cell Biol. 126, 1079-1088

8. Jiang, Z., Seo, J. Y., Ha, H., Lee, E. A., Kim, Y. S., Han, D. C., Uh, S. T., Park, C. S., and Lee, H. B. (2003) Reactive oxygen species mediate TGF-beta1-induced plasminogen activator inhibitor-1 upregulation in mesangial cells. Biochem. Biophys. Res. Commun. 309, 961-966

9. Iglesias-De La Cruz, M. C., Ruiz-Torres, P., Alcami, J., Diez-Marques, L., OrtegaVelazquez, R., Chen, S., Rodriguez-Puyol, M., Ziyadeh, F. N., and Rodriguez-Puyol, D. (2001) Hydrogen peroxide increases extracellular matrix mRNA through TGF-beta in human mesangial cells. Kidney Int. 59, 87-95

10. Garcia-Trevijano, E. R., Iraburu, M. J., Fontana, L., Dominguez-Rosales, J. A., Auster, A., Covarrubias-Pinedo, A., and Rojkind, M. (1999) Transforming growth factor beta1 induces the expression of alpha1(I) procollagen mRNA by a hydrogen peroxide-C/EBPbetadependent mechanism in rat hepatic stellate cells. Hepatology 29, 960-970

11. Li, W. Q., Qureshi, H. Y., Liacini, A., Dehnade, F., and Zafarullah, M. (2004) Transforming growth factor beta1 induction of tissue inhibitor of metalloproteinases 3 in articular chondrocytes is mediated by reactive oxygen species. Free Radic. Biol. Med. 37, 196-207

12. Thannickal, V. J., and Fanburg, B. L. (1995) Activation of an H2O2-generating NADH oxidase in human lung fibroblasts by transforming growth factor beta 1. J. Biol. Chem. 270, 30334-30338

13. Horowitz, J. C., Lee, D. Y., Waghray, M., Keshamouni, V. G., Thomas, P. E., Zhang, H., Cui, Z., and Thannickal, V. J. (2004) Activation of the pro-survival phosphatidylinositol 3kinase/AKT pathway by transforming growth factor-beta1 in mesenchymal cells is mediated by p38 MAPK-dependent induction of an autocrine growth factor. J. Biol. Chem. 279, 1359-1367

14. Thannickal, V. J., Aldweib, K. D., and Fanburg, B. L. (1998) Tyrosine phosphorylation regulates $\mathrm{H} 2 \mathrm{O} 2$ production in lung fibroblasts stimulated by transforming growth factor beta1. J. Biol. Chem. 273, 23611-23615

15. Thannickal, V. J., Lee, D. Y., White, E. S., Cui, Z., Larios, J. M., Chacon, R., Horowitz, J. C., Day, R. M., and Thomas, P. E. (2003) Myofibroblast differentiation by transforming growth factor-beta1 is dependent on cell adhesion and integrin signaling via focal adhesion kinase. J. Biol. Chem. 278, 12384-12389 
16. Thannickal, V. J., Aldweib, K. D., Rajan, T., and Fanburg, B. L. (1998) Upregulated expression of fibroblast growth factor (FGF) receptors by transforming growth factor-beta1 (TGF-beta1) mediates enhanced mitogenic responses to FGFs in cultured human lung fibroblasts. Biochem. Biophys. Res. Commun. 251, 437-441

17. Kazzaz, J. A., Xu, J., Palaia, T. A., Mantell, L., Fein, A. M., and Horowitz, S. (1996) Cellular oxygen toxicity. Oxidant injury without apoptosis. J. Biol. Chem. 271, 1518215186

18. Geiser, T., Ishigaki, M., van Leer, C., Matthay, M. A., and Broaddus, V. C. (2004) H(2)O(2) inhibits alveolar epithelial wound repair in vitro by induction of apoptosis. Am. J. Physiol. Lung Cell. Mol. Physiol. 287, L448-L453

19. Uhal, B. D., Joshi, I., Hughes, W. F., Ramos, C., Pardo, A., and Selman, M. (1998) Alveolar epithelial cell death adjacent to underlying myofibroblasts in advanced fibrotic human lung. Am. J. Physiol. 275, L1192-L1199

20. Maeyama, T., Kuwano, K., Kawasaki, M., Kunitake, R., Hagimoto, N., Matsuba, T., Yoshimi, M., Inoshima, I., Yoshida, K., and Hara, N. (2001) Upregulation of Fas-signalling molecules in lung epithelial cells from patients with idiopathic pulmonary fibrosis. Eur. Respir. J. 17, 180-189

21. Uhal, B. D. (2003) Epithelial apoptosis in the initiation of lung fibrosis. Eur. Respir. J. Suppl. 44, 7s-9s

22. (2000) American Thoracic Society. Idiopathic pulmonary fibrosis: diagnosis and treatment. International consensus statement. American Thoracic Society (ATS), and the European Respiratory Society (ERS). Am. J. Respir. Crit. Care Med. 161, 646-664

23. Krysko, O., De Ridder, L., and Cornelissen, M. (2004) Phosphatidylserine exposure during early primary necrosis (oncosis) in JB6 cells as evidenced by immunogold labeling technique. Apoptosis 9, 495-500

24. Larios, J. M., Budhiraja, R., Fanburg, B. L., and Thannickal, V. J. (2001) Oxidative protein cross-linking reactions involving L-tyrosine in transforming growth factor-beta1-stimulated fibroblasts. J. Biol. Chem. 276, 17437-17441

25. O’Donnell, B. V., Tew, D. G., Jones, O. T., and England, P. J. (1993) Studies on the inhibitory mechanism of iodonium compounds with special reference to neutrophil NADPH oxidase. Biochem. J. 290, 41-49

26. Fujita, T., Maruyama, M., Araya, J., Sassa, K., Kawagishi, Y., Hayashi, R., Matsui, S., Kashii, T., Yamashita, N., Sugiyama, E., et al. (2002) Hydrogen peroxide induces upregulation of Fas in human airway epithelial cells via the activation of PARP-p53 pathway. Am. J. Respir. Cell Mol. Biol. 27, 542-552 
27. Ye, J., Wang, S., Leonard, S. S., Sun, Y., Butterworth, L., Antonini, J., Ding, M., Rojanasakul, Y., Vallyathan, V., Castranova, V., et al. (1999) Role of reactive oxygen species and p53 in chromium(VI)-induced apoptosis. J. Biol. Chem. 274, 34974-34980

28. Denning, T. L., Takaishi, H., Crowe, S. E., Boldogh, I., Jevnikar, A., and Ernst, P. B. (2002) Oxidative stress induces the expression of Fas and Fas ligand and apoptosis in murine intestinal epithelial cells. Free Radic. Biol. Med. 33, 1641-1650

29. Hagimoto, N., Kuwano, K., Inoshima, I., Yoshimi, M., Nakamura, N., Fujita, M., Maeyama, T., and Hara, N. (2002) TGF-beta 1 as an enhancer of Fas-mediated apoptosis of lung epithelial cells. J. Immunol. 168, 6470-6478

30. Kuwano, K., Miyazaki, H., Hagimoto, N., Kawasaki, M., Fujita, M., Kunitake, R., Kaneko, Y., and Hara, N. (1999) The involvement of Fas-Fas ligand pathway in fibrosing lung diseases. Am. J. Respir. Cell Mol. Biol. 20, 53-60

31. Kuwano, K., Hagimoto, N., Maeyama, T., Fujita, M., Yoshimi, M., Inoshima, I., Nakashima, N., Hamada, N., Watanabe, K., and Hara, N. (2002) Mitochondria-mediated apoptosis of lung epithelial cells in idiopathic interstitial pneumonias. Lab. Invest. 82, 16951706

32. Wang, R., Ramos, C., Joshi, I., Zagariya, A., Pardo, A., Selman, M., and Uhal, B. D. (1999) Human lung myofibroblast-derived inducers of alveolar epithelial apoptosis identified as angiotensin peptides. Am. J. Physiol. 277, L1158-L1164

33. Wang, R., Zagariya, A., Ang, E., Ibarra-Sunga, O., and Uhal, B. D. (1999) Fas-induced apoptosis of alveolar epithelial cells requires ANG II generation and receptor interaction. Am. J. Physiol. 277, L1245-L1250

34. Tomasek, J. J., Gabbiani, G., Hinz, B., Chaponnier, C., and Brown, R. A. (2002) Myofibroblasts and mechano-regulation of connective tissue remodelling. Nat. Rev. Mol. Cell Biol. 3, 349-363 
Fig. 1

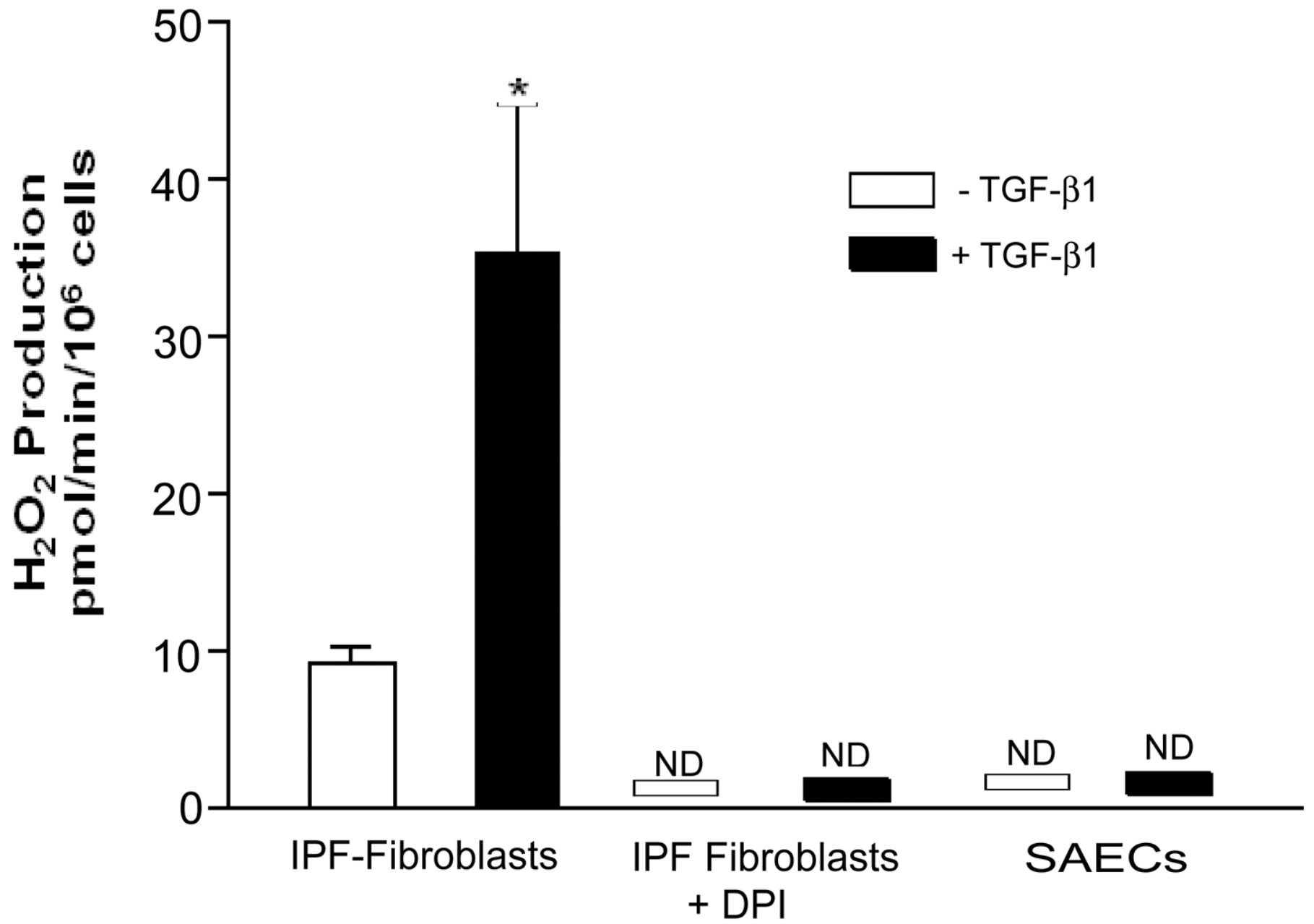

Figure 1. TGF- $\beta 1$ induces extracellular $\mathrm{H}_{2} \mathrm{O}_{2}$ release from IPF fibroblasts, but not SAECs. IPF fibroblasts were grown to $80-90 \%$ confluence, serum-starved for $24 \mathrm{~h}$, and treated with or without TGF- $\beta 1$ ( $2 \mathrm{ng} / \mathrm{ml})$ for $16 \mathrm{~h}$ in the presence or absence of diphenyliodonium (DPI, $10 \mu \mathrm{M}$ added $30 \mathrm{~min}$ before assay). SAECs were grown to near confluence and treated with or without TGF- $\beta 1(2 \mathrm{ng} / \mathrm{ml})$ for $16 \mathrm{~h}$ before $\mathrm{H}_{2} \mathrm{O}_{2}$ measurements. $\mathrm{H}_{2} \mathrm{O}_{2}$ was assayed using a fluorescencebased assay as described in Materials and Methods. Values represent mean \pm SE $(n=4, * P<0.05$ vs. control/without TGF$\beta 1)$. ND = not detectable. 
Fig. 2

A

\section{SAECs}

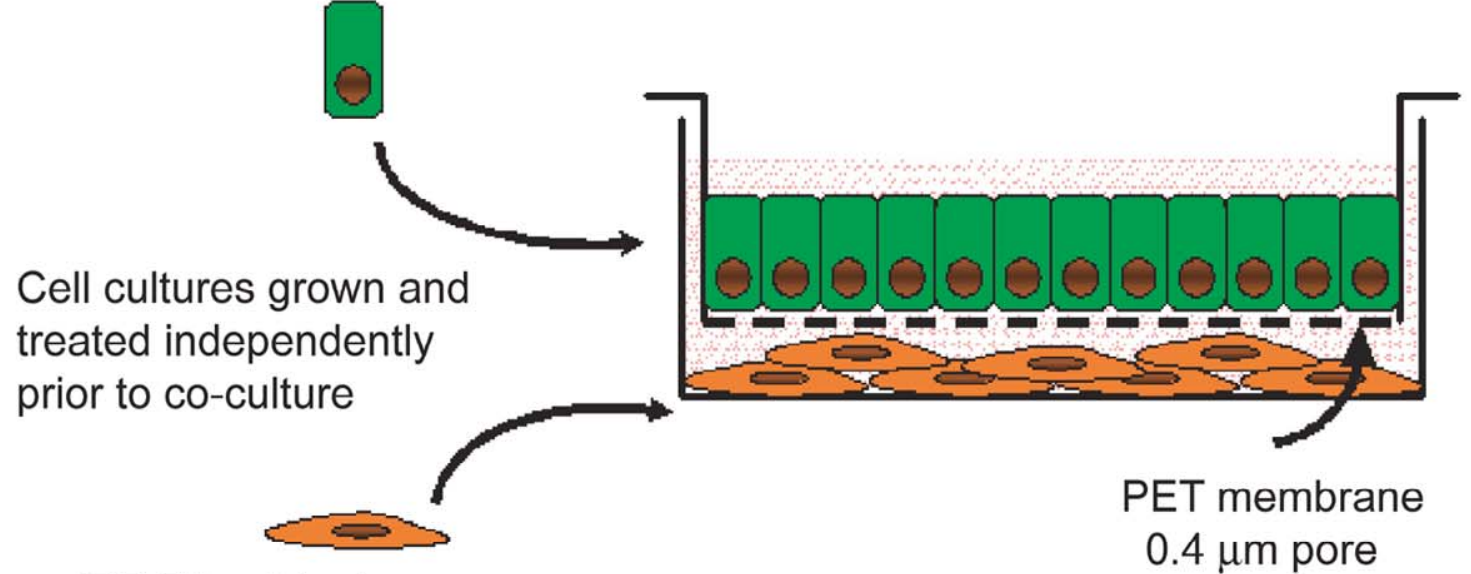

IPF Fibroblasts

(TGF- $\beta 1$ pre-treated)

B

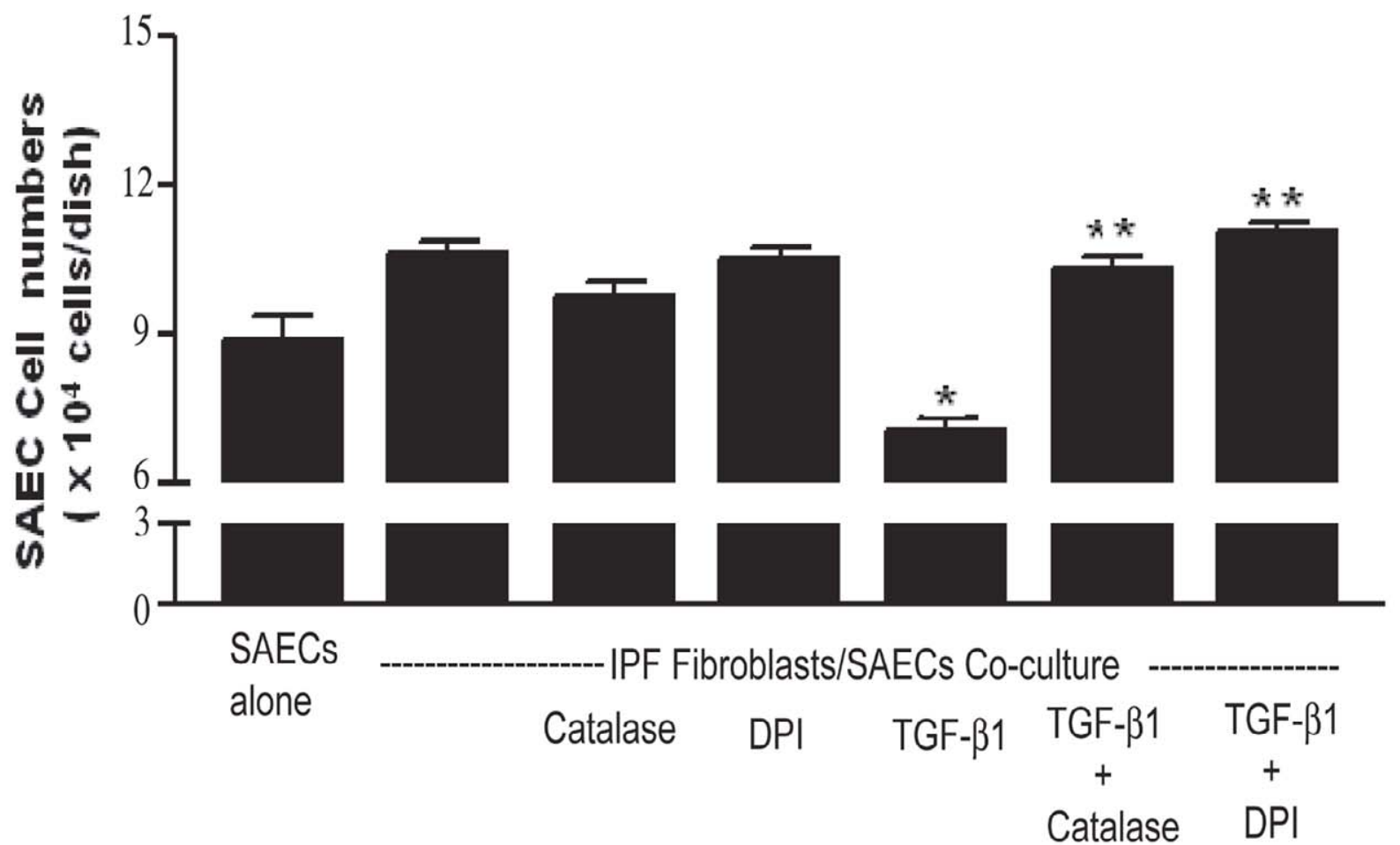

Figure 2. TGF- $\beta 1$ signaling of IPF fibroblasts induces $\mathrm{H}_{2} \mathrm{O}_{2}$-mediated loss of SAEC viability. $A$ ) Coculture system of epithelial cells and fibroblasts. IPF fibroblasts and SAECs were grown separately on the lower wells and upper chambers, respectively, of a Transwell coculture system. IPF fibroblasts were growth-arrested at 80-90\% confluence, stimulated with or without TGF- $\beta 1$, and washed twice before coculture. SAECs were grown to near confluence before coculture. $\boldsymbol{B})$ Effects of TGF- $\beta 1$-stimulated IPF fibroblasts on viability of SAECs. IPF fibroblasts pretreated with or without TGF- $\beta 1$ ( $2 \mathrm{ng} / \mathrm{ml})$ for $16 \mathrm{~h}$ in the absence or presence of diphenyliodonium (DPI, $10 \mu \mathrm{M}$ added $30 \mathrm{~min}$ before coculture) were washed before introduction of SAECs. Catalase $(3000 \mathrm{U} / \mathrm{ml})$ was added to coculture media for the duration of coculture. Cell numbers were assessed following $48 \mathrm{~h}$ of coculture by Coulter counting. Values represent mean $\pm \mathrm{SE}(n=3 ; * P<0.05$ vs. coculture without TGF- $\beta 1 ; * * P<0.05$ vs. coculture with TGF- $\beta 1)$. Three replicate experiments demonstrated similar results. 
Fig. 3

A

IPF Fibroblasts/SAECs Co-culture
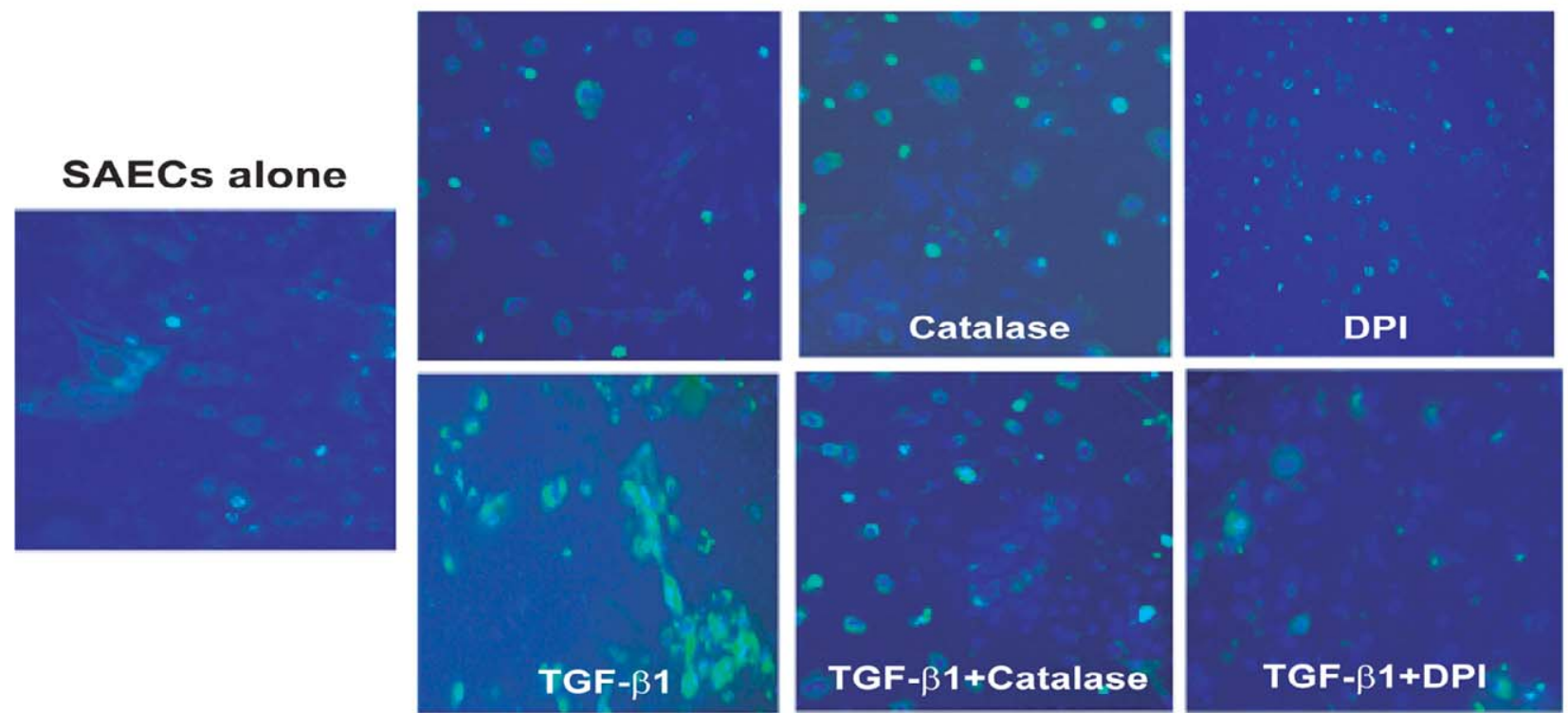

B

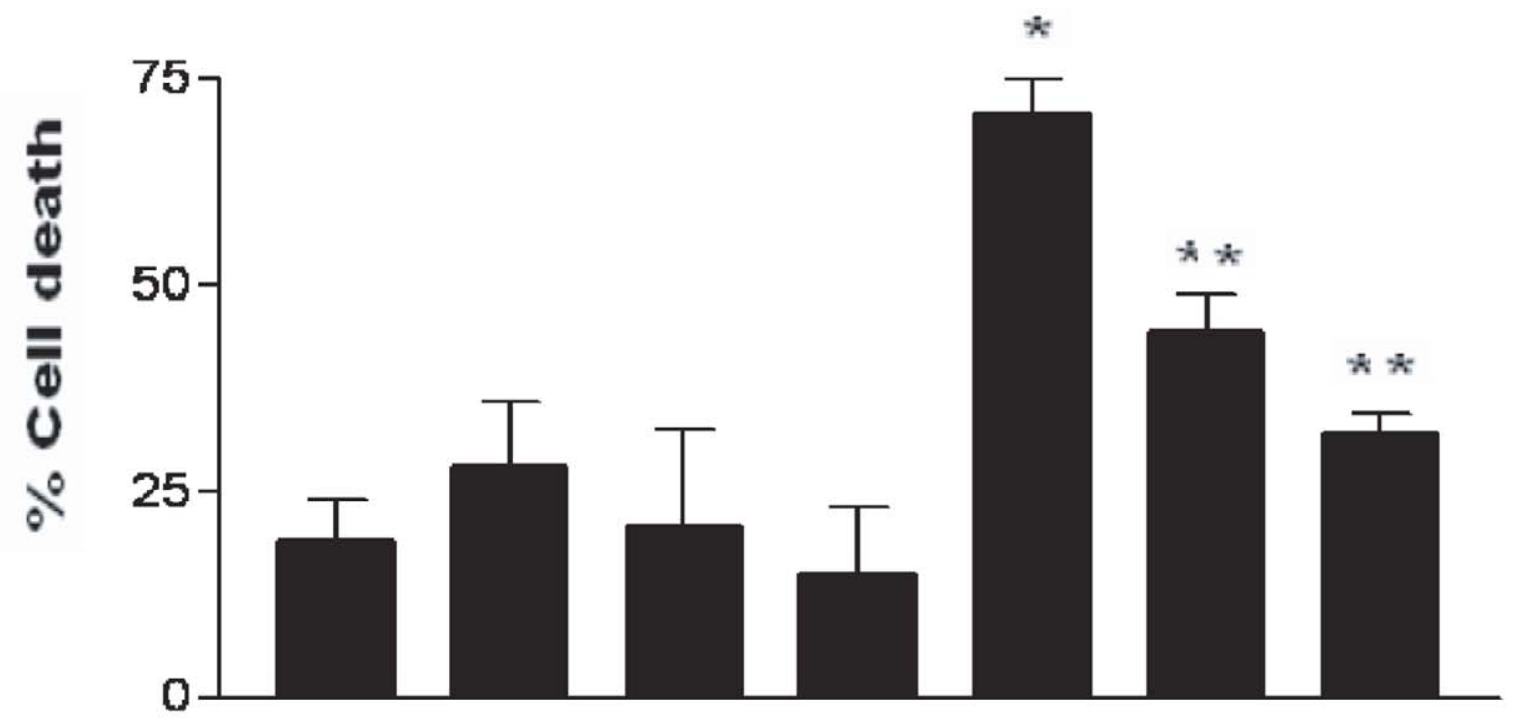

Figure 3. $\mathrm{H}_{2} \mathrm{O}_{2}$ secretion by TGF- $\beta 1$-stimulated IPF fibroblasts mediates SAEC death. $A$ ) Immunofluorescence staining of SAECs in coculture. IPF fibroblasts and SAECs were grown separately on the lower wells and upper chambers, respectively, of a Transwell coculture system. IPF fibroblasts pretreated with or without TGF- $\beta 1$ ( $2 \mathrm{ng} / \mathrm{ml})$ for $16 \mathrm{~h}$ in the absence or presence of diphenyliodonium (DPI, $10 \mu \mathrm{M}$ added $30 \mathrm{~min}$ before coculture) were washed before introduction of SAECs. Catalase $(3000 \mathrm{U} / \mathrm{ml})$ was added to coculture media for the duration of coculture. Immunofluorescence staining for detection of phosphatidylserine (PS) was performed as described in Materials and Methods. B) Quantitative assessment of apoptotic rates in SAECs. Percentage cell death was quantitated by dividing PS (+) cells by the total number of cells in 3 separate fields containing at least 100 cells per field. $(n=6, * P<0.05$ vs. control/without TGF- $\beta 1 ; * * P<0.05$ vs. coculture with TGF- $\beta 1)$. 
Fig. 4

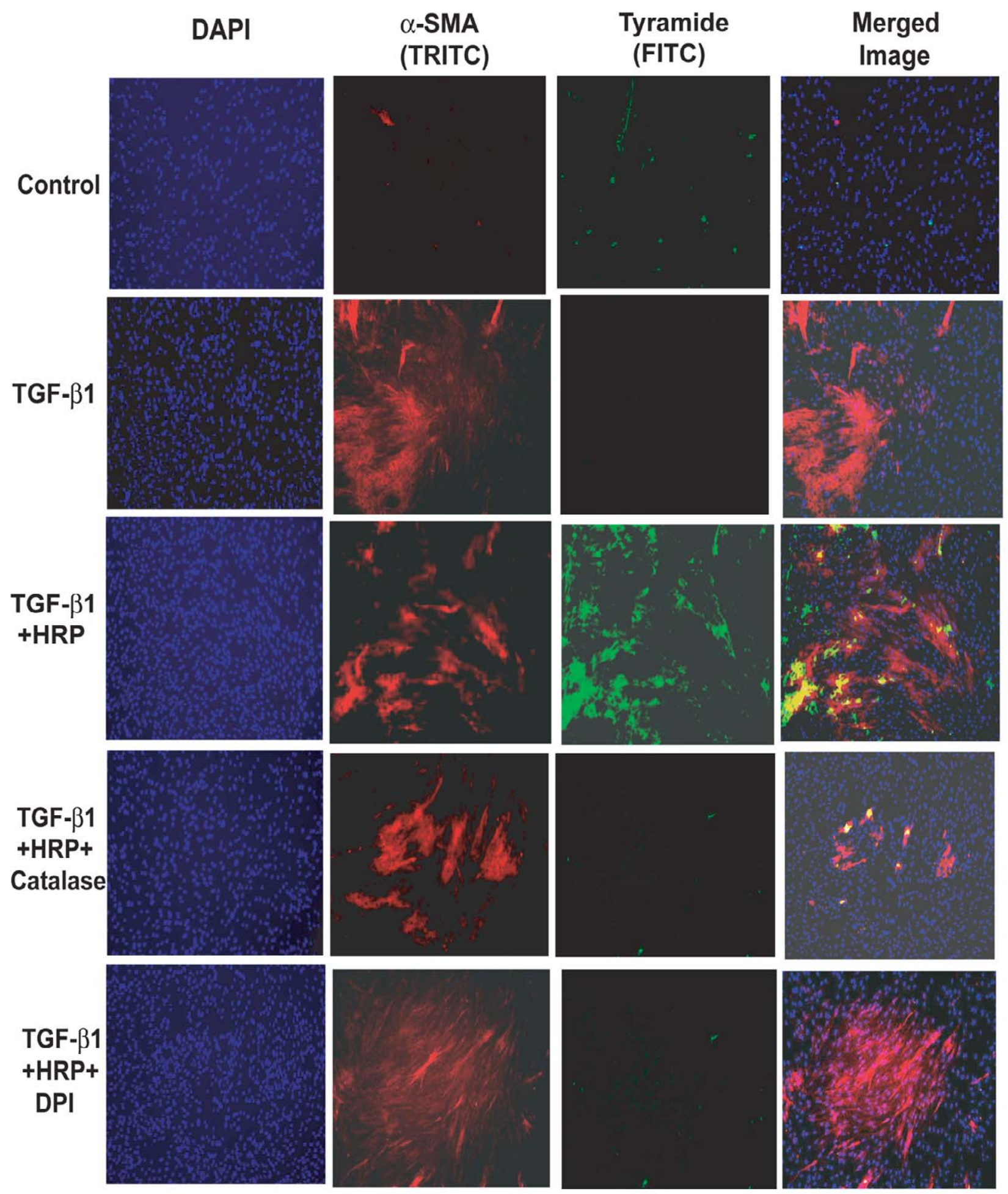

Figure 4. Localization of cellular $\mathrm{H}_{2} \mathrm{O}_{2}$ production. IPF fibroblasts were grown to 80-90\% confluence, serum-starved for $24 \mathrm{~h}$, and treated with or without TGF- $\beta 1(2 \mathrm{ng} / \mathrm{ml})$ for $16 \mathrm{~h}$. Cells were washed and incubated in assay medium containing tyramide-FITC (green) in the absence or presence of horseradish peroxidase (HRP; $5 \mathrm{U} / \mathrm{ml}$ ), catalase ( $3000 \mathrm{U} / \mathrm{ml}$, coincubated during the assay period), and DPI (10 $\mu \mathrm{M}$, added $30 \mathrm{~min}$ before assay) for $1 \mathrm{~h}$. Cells were then washed, fixed, and stained for $\alpha$-smooth muscle actin (SMA) with secondary antibody conjugated to TRITC (red). Counterstaining for nuclei was with DAPI (blue). 
Fig. 5

Heterogeneous

IPF fibroblasts
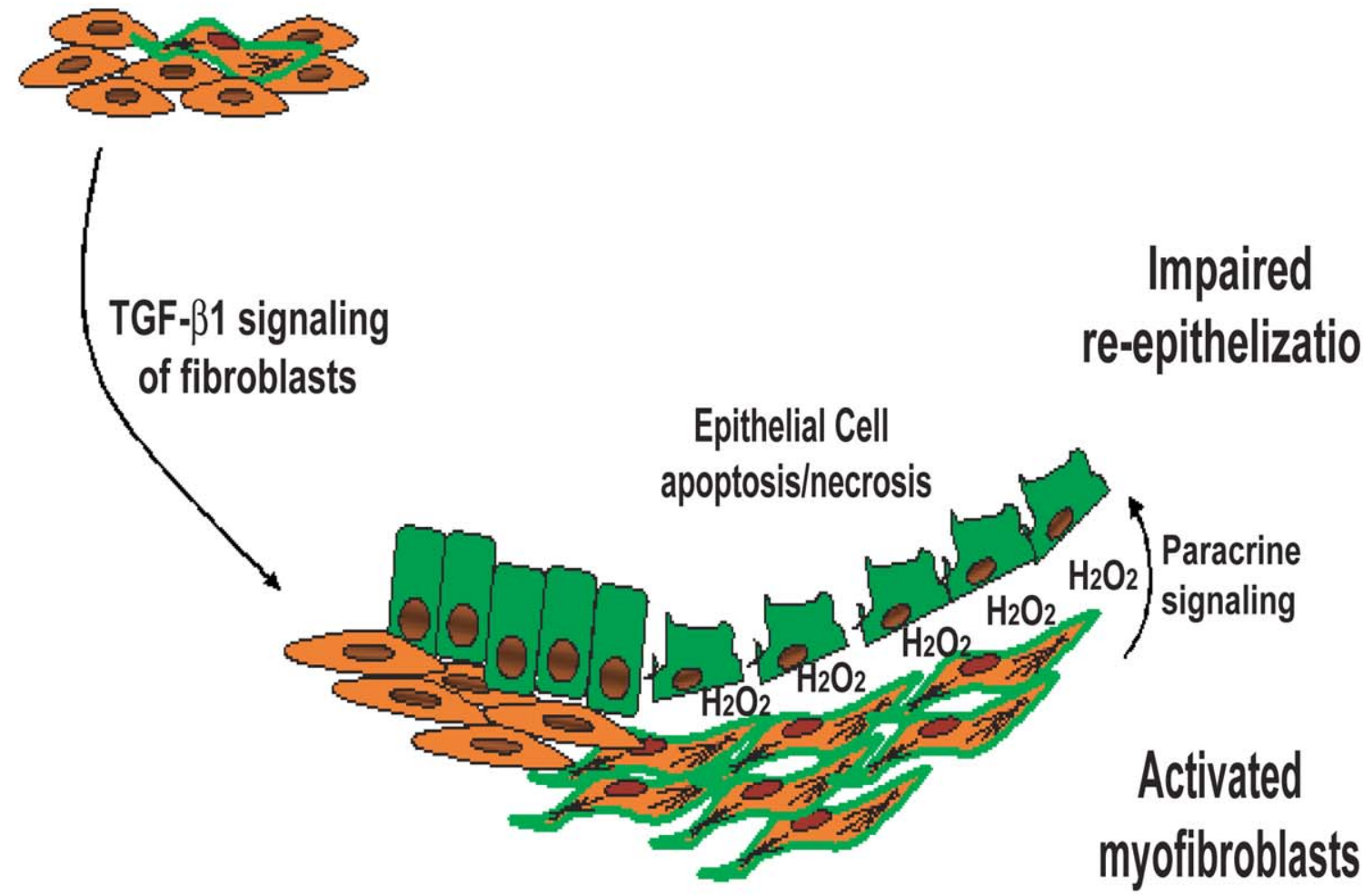

FIBROSIS

Figure 5. $\mathrm{H}_{2} \mathrm{O}_{2}$ secreted by myofibroblasts is a diffusible, paracrine mediator of epithelial cell death. IPF tissuederived fibroblasts represent a heterogeneous population of cells, including myofibroblasts. TGF- $\beta 1$ signaling of IPF fibroblasts induces death of adjacent epithelial cells. This effect is mediated, at least in part, by diffusible paracrine signaling by $\mathrm{H}_{2} \mathrm{O}_{2}$. Myofibroblasts are the principal cells responsible for extracellular $\mathrm{H}_{2} \mathrm{O}_{2}$ production. This novel mechanism for paracrine signaling by $\mathrm{H}_{2} \mathrm{O}_{2}$ may be important in the dysregulated epithelial-mesenchymal crosstalk that characterizes chronic fibrotic diseases. 